\title{
Reconstruction of the Educational Model for Improving the Practical Teaching Ability of Graduate Students Majoring in Physical Education
}

\author{
Lizhong Wen \\ College of Sports Science \\ Jishou University \\ Jishou, 416000 China \\ Wenlizhong1107@163.com
}

\author{
Yufeng Chen \\ College of Sports Science \\ Jishou University \\ Jishou, 416000 China \\ 278670622@163.com
}

\begin{abstract}
In China, the training mode of master of physical education is gradually enriched. However, most colleges pay attention to cultivating academic masters for training masters. There are much more in theoretical research and relatively less in the practical teaching model. This can't meet the needs of socie ty for high-quality professional talents. This article outlines the four constituent elements of the practical ability of postgraduates majoring in sports masters, and the current state of demand in modern society. It also analyzes the reasons why colleges and universities have not fully understood the practical ability of masters in physical education, the lack of perfect curriculum in universities, and the discrepancy between teaching goals and social needs. Finally, it is pointed out that colleges and universities should set up the correct educational practice of sports professional masters, perfect the master's curriculum system of sports professional meeting the needs of the society, and establish the educational mode of sports professional master's education practice system. So as to provide more reference for the training of master of physical education in practice.
\end{abstract}

Keywords-Master of Physical Education; Practice Teaching; Reconstruction of Educational Model

\section{INTRODUCTION}

In 2005, the State Council adopted the Master Program in Sports Education, which set a master's degree in sports. Since then, China has also begun to develop high-quality; high-level sports professionals as a need to build quality education with a professional degree. This is also an important transformation of professional training in China. It indicates that the training of master's talents in China began to be oriented towards the education of applied talents.

Although the state has put forward relevant policies to guide the development of master's degree in physical education, there are still many problems in the actual development. Such as the lack of relevant experience, there is no specific standard for the training mode of the sports majors, the curriculum is not reasonable and so on. Therefore, in China, the practice teaching of master of physical education should be paid attention to in all aspects. In sports teaching, practice teaching is closely related to the education of sports professional masters. It can't

Fund Project: Research project of the 2017 degree and graduate education reform of Jishou University (JG2017B06)

Introduction: Wen Li Zhong(1984-), male, Hunan Liling people, master's degree, lecturer, mainly engaged in sports theory and practice research only improve the professional ability of sports professional masters in the future social practice, but also cultivate richer social experience for college students. Therefore, improving the practical ability of masters in education is an important measure to enhance the reconstruction of education mode, and it is also capable of cultivating high-quality sports professionals for the society.

\section{COMPONENTS OF PRACTICAL CAPACITY}

In China, there is still less research on the constituent elements of the practical teaching for the master of physical education in Colleges and universities, and there is no unified research standard in the research results. Therefore, many studies do not consider the cultivation of the practical ability of the master's degree as a special subject. The training of practice teaching for master of physical education is an important basis for professional curriculum design and professional teaching plan. It is also a major criterion for training target orientation and teaching content in future professional teaching. There are four basic elements that can be divided into: general practice, practical motivation, special practice and situational practice ability[1]. In order to build a practical teaching ability education mode to improve the master's degree in physical education, we must first analyze the four major components, carry out the curriculum reform and formulate the talent cultivation plan. In the direction of training the actual physical education master's degree, we should combine with the four basic elements.

\section{STATE OF DEMAND IN MODERN SOCIETIES}

With the expansion of the physical education master's degree in colleges and universities, there is still a great demand for the professional practice ability of the master of physical education. In the master's degree of professional practice ability requirements are not the same. For example, we have certain expression and communication skills in the requirements of general practical ability. We must have a sense of teamwork and cooperation in our work and be able to perceive some professional problems. These as the general practice ability, in the special practice ability and the different ability have certain demand. However, different social practice units are different in their practical ability requirements for master of physical 
education. For example, the sports education department is more focused on the ability of physical education for the master of physical education. Another example is the social sports guidance department, the demand for master of physical education is more emphasis on the comprehensive ability of all aspects of the situation. Because of the different nature of the work, the competition organization department focuses more on the ability of organizing the different events and managing the events affairs. At present, domestic colleges and universities in the practical teaching mode of physical education professional master is not perfect, so many employers in the community in the master of professional sports in the professional practice ability is not very satisfactory, solid University in practice teaching ability need to be further enhanced. [2]

\section{ANALYSIS OF THE REASONS FOR THE NON-CONFORMITY OF SOCIAL DEMAND IN PRACTICE EDUCATION.}

There are still great differences in the practice ability and the social demand for the master of physical education. This is due to the different units of the PE Master's social practical ability needs. In the sports training unit, for example, the competency of the master's degree in physical education focuses on communication and communication skills, the management and organization of some sporting events, as well as teamwork skills and a greater need for physical health skills. However, the master of physical education in colleges and universities is generally poor in these abilities, and can't meet the needs of social practice units for sports professional master, so there are great differences between them. Then there is the social practice unit to some special sports in the innovative ability and some training capacity needs more, and this practical ability is just the lack of the master of physical education. This indicates that there are still serious deficiencies in the cultivation of professional practice ability of sports majors in many universities in China. The reasons for this difference lie in the following aspects.

\section{A. Lack of awareness of the practice ability of college students majoring in physical education}

In colleges and universities, the training of master of physical education should adhere to the principle of "people first" and regard comprehensive and sustainable development as the core of cultivating talents. Therefore, based on the teaching of sports basic knowledge, we should further enhance the training of sports professional masters in some practical problems, so as to better undertake the responsibilities of social practice. Colleges and universities should have higher professional practice ability in the education of master of physical education, so as to cultivate high level sports talents for the society. Throughout many schools in China, there are great deficiencies in the training mode and curriculum setting of sports majors, especially for sports professional masters. Therefore, if we should use the previous teaching model, it is impossible to adapt to the needs of the modern society for the master of physical education. Only by improving the understanding of the practical ability of the master of physical education, can we better cultivate the sports talents with strong and creative ability for the society.

\section{B. The courses set up by the universities are not perfect and are separated from the social practice}

There is a lack of innovation in curriculum design in universities. As a necessary condition for the closer professional curriculum and practice, it is necessary to improve the curriculum. However, many colleges and universities in China are similar in the design of some basic courses, lack of innovation, especially some of the courses set up on the high repeatability, and on the professional study of the relevance of the master is not relevant, resulting in theoretical learning can't be linked with the practice, ultimately leading to the curriculum design and social practice separated.

\section{The gap between the teaching goal of the Master of Physical education and the social demand in universities}

With the emphasis on sports in China, the domestic sports cause has been better developed. After the government put forward the Outline of the National Fitness Program, People's participation in sports is becoming more and more complex. The sports departments in the society are more and more demanding and demanding for sports professionals. In the demand for sports professionals, we must grasp the theoretical knowledge and practical ability, which can be applied to the management of sports departments and some professional technology. At present, some sports masters can't meet the needs of the social sports professionals in the job position, and can't meet the requirements of the social sports development. The reason is that colleges and universities have great differences in the educational concept, the training goal of talents and the needs of the society.

\section{WAys to Restructure the Educational Model of ENHANCING THe Practical TEACHING ABILITy OF MAsters IN PHYSICAL EDUCATION}

\section{A. Universities should set up a correct thought of practical education for masters in physical education}

There remains a lack of long-term understanding in the cultivation of the practice ability of a professional master in sports, which have had severe influence on cultivating the master's capability. Thus, it is requisite to set up the concept of correctly training the practical ability of the master if the improvement on its educational pattern and training objectives is needed. First, in view of the requirement for the intellectual on social development, the comprehensive understanding about the master's capability is necessary. What' more, the university should implement the promotion on teaching practical ability and strengthen the cultivation on professional practice, in the hope of providing the top talents in sports for our society. Second, except for an array of rudimentary practical capability to forge, such as the ability on team's creativity, communication, organization and facilities using, training on other capabilities, as are to be technological creativity, umpiring on events and physical caring, is essential. In a conclusion, the ideal educational method ought to be overall development on practical ability of sports profession. [3] 


\section{B. To improve the master's program in physical culture and sports to meet the requirements of society}

In the sports master's curriculum to meet the training of master's degree in sports specialty, in the curriculum set to be consistent with the teaching and training objectives. In order to be able to better integrate with social practice, the curriculum should have some creativity. For example, the teaching method is innovative, and the theoretical knowledge can be combined with practice, so that the training of professional practice ability can be highlighted. Secondly, in the teaching plan, the proportion of practical elective courses should be increased. This can increase students' chances of practicing and help students to broaden their horizons and increase their enthusiasm for learning professional knowledge. In the teaching of physical education, we should focus on practical education. We should learn from other disciplines' curriculum settings in order to cultivate students' individualized development as the purpose and better optimize the practice ability of students.

\section{Establishment of a master's education practice system for sports majors}

It is necessary to establish and improve the educational practice system for the master of physical education. In the teaching plan of colleges and universities, practice training for students is also an important way to improve their practical ability. The practice of education practice can't only increase the professional practice experience, but also add the ability of dealing with some events. Therefore, it is of great significance to improve students 'practical ability and future career development to carry out the perfect educational practice system. Through cooperation with some social units, colleges and universities can serve as long-term practice bases for students with certain ability to practice in practice bases, better to practice professional ability; it is also possible to practice on campus, such as watching and studying in some of the public sports practice classes offered by the tutors. Through these ways, we can increase students' practice and create more internship opportunities for students, so that students can improve their quality and ability in practice.

\section{CONCLUSION}

The training of graduate masters in sports master degree is of great significance in the training of applied sports talents in China. The improvement of practical ability is an important part of professional master's training. This article proposes that colleges and universities should establish a correct physical education master's practical education idea, improve the sports professional master's program system that meets the needs of the society and establish the effective education mode approach for the sports professional master education internship system. We also need to continue to summarize the implementation of the training mode, and use the spirit of continuous innovation to improve the professional master training model with practical ability training as the core.

\section{REFERENCES}

[1] Ji Changai. Research on the cultivation of professional practice ability of master degree of master degree of full-time physical education. [D]. Ningbo university. 2012(1)(In Chinese)

[2] Han tong. Study on the target and characteristics of full-time master degree in physical education[J]. Sports science and technology literature bulletin. 2014(09):41-46. (In Chinese)

[3] Yang Lili. Study on the problems and countermeasures of the retest of full-time master of physical education[J]. Sports science and technology literature bulletin. 2014(06):147-151. (In Chinese)

[4] Fang Qianhua, Huang Hansheng, Zhu guilin. The dilemma and way of postgraduate training of full-time master of sports in China. [J]. Journal of Shanghai sports institute. . 2014(06):79-83. (In Chinese)

[5] Xiong Shurong. Reflections on some problems of education degree of master of physical education. [J]. Journal of Beijing sports university. . 2007(08):1100-1101. (In Chinese) 